\title{
Sheehan's syndrome with central diabetes insipidus
}

\author{
Síndrome de Sheehan e diabetes insípido central
}

Bashir Ahmad Laway', Shahnaz Ahmad Mir', Mohd Iqbal Dar', Abdul Hamid Zargar ${ }^{1}$

\section{SUMMARY}

Sheehan's syndrome refers to the occurrence of hypopituitarism after delivery, usually preceded by postpartum hemorrhage. The condition still continues to be a common cause of hypopituitarism in developing countries like India. The disorder usually presents with anterior pituitary failure with preservation of posterior pituitary functions. Posterior pituitary dysfunction in the form of central diabetes insipidus is rare in patients with Sheehan's syndrome. We describe the clinical course of a young lady who after her sixth childbirth developed severe postpartum hemorrhage followed by development of panhypopituitarism which was confirmed by hormonal investigation and demonstration of empty sella on imaging. In addition, she developed Polyuria. The water deprivation test and response to vasopressin test results indicated central diabetes insipidus. She needed oral desmopressin on a continuous basis to control polyuria. Arq Bras Endocrinol Metab. 2011;55(2):171-4

Keywords

Sheehan's syndrome; central diabetes insipidus; water deprivation test

\section{SUMÁRIO}

A síndrome de Sheehan está relacionada à ocorrência de hipopituitarismo pós-parto, geralmente precedido por hemorragia pós-parto. Essa condição clínica ainda constitui causa comum do hipopituitarismo observado em países em desenvolvimento como a Índia. Essa síndrome se caracteriza pela insuficiência da glândula hipofisária anterior, porém com a conservação das funções da glândula hipofisária posterior. A disfunção da hipófise posterior, sob a forma de diabetes insipidus central, é algo raramente observado em pacientes que apresentam a síndrome de Sheehan. Neste artigo, descrevemos o caso de uma jovem que, após o sexto parto, apresentou hemorragia pós-parto grave, seguida pela evolução de pan-hipopituitarismo que foi confirmado por pesquisa hormonal e exames de imagem que evidenciaram sela vazia. A jovem também apresentou poliúria. Os resultados do teste de privação de água e exame de resposta à vasopressina indicaram diabetes insípido central. A paciente fazia uso contínuo de desmopressina para controlar a poliúria. Arq Bras Endocrinol Metab. 2011;55(2):171-4

\section{Descritores}

Síndrome de Sheehan; diabetes insípido central; teste de privação de água

\author{
${ }^{1}$ Department of Endocrinology, \\ SKIMS, Soura, Srinagar, \\ Jammu and Kashmir India
}

Correspondence to: zargarah123@gmail.com

Received on Dec/30/2010 Accepted on Fev/2/2011
$S^{\text {h }}$ heehan's syndrome (SS) presents with anterior pituitary hormone deficiency after child birth. Hypopituitarism results as a consequence of infarction and necrosis of the physiologically enlarged pituitary gland during pregnancy which is usually preceded by postpartum hemorrhage. Pituitary enlargement during pregnancy results in compression of the superior hypophyseal artery. Any hypotension during delivery causes arterial spasm in smaller vessels, apoplexy, and subsequent pituitary necrosis (1).The syndrome manifests with lactation failure, amenorrhea, involution of the breasts, and loss of axillary and pubic hair and of features typical of other anterior pituitary hormone deficiencies (2). Pathogenesis of SS is not clear. A role of autoimmunity in the development of hypopituitarism has been suggested. It is believed that tissue necrosis may release sequestered antigens, triggering pituitary autoimmunity and delayed hypopituitarism (3). Most patients present with either complete or partial hypofunction of the anterior pituitary (4-6). Although subtle posterior pituitary distur- 
bances in these patients have been reported, complete central diabetes insipidus (CDI) is rare and most cases are reported before the availability of magnetic resonance imaging (7-9). We report the clinical course of a case of Sheehan's syndrome who also presented with severe polyuria during follow-up and on investigation was found to have CDI which responded to oral desmopressin.

\section{CASE REPORT}

A 35-year-old woman delivered her sixth child, developed massive postpartum bleeding, and received three units of blood after hospitalization three years before seeking us. After delivery she failed to lactate, did not menstruate and was fatigable. A year earlier, she had also started noticing excessive thirst and polyuria. Examination revealed blood pressure of $95 / 60 \mathrm{mmHg}$, facial hypopigmentation, breast atrophy, absent axillary and pubic hair with features of hypothyroidism. Investigation revealed anemia ( $\mathrm{Hb}$ of $9.3 \mathrm{~g} / \mathrm{dL}$, thrombocytopenia (platelet count of $66^{\prime} 10^{3}$ ) with normal leukocyte count. Biochemical investigation revealed normal glucose, sodium, potassium, urea, creatinine, and calcium levels. Her chest X-ray and electrocardiogram were within normal limits. Basal hormone estimations revealed undetectable serum total thyroxine (T4), inappropriately normal thyroid stimulating hormone (TSH) with low basal cortisol, growth hormone (GH), prolactin (PRL), and gonadotrophins; features suggestive of panhypopituitarism (Table 1). Magnetic resonance imaging (MRI) of the pituitary revealed evidence of completely empty sella (Figure 1). The patient was put on replacement receiving thyroxine $75 \mu \mathrm{g} /$ day and prednisolone $5 \mathrm{mg} /$ day. Some of her symptoms started improving over the following two weeks but polyuria worsened, urinary volume increased from 4.5 to 6 liters/day. The patient was discharged and was readmitted after two months for evaluation of polyuria and water deprivation test was planned. The procedure of the water deprivation test was explained to the patient and her spouse and informed consent was obtained from both of them. The patient was subjected to the Miller procedure water deprivation test (10). She was deprived of food and water from 9 p.m. in the evening before the test. Her weight, blood pressure, urine volume, urinary osmolality, plasma sodium, and glucose were measured at 7 o'clock in the morning; her weight, blood pressure, urine volume, and urine osmolality were measured hourly until urinary osmolality stabilized. At this time, plasma sodium and osmolality were measured and 5 units of arginine vasopressin (AVP) were administered subcutaneously. Subsequently, urine and plasma osmolality were measured every thirty minutes for next 90 minutes. The patient's husband was also submitted to the tests in the same manner and acted as a control. The patient's urinary osmolality stabilized at around 16 hours of water deprivation when simultaneous plasma osmolality was $300 \mathrm{mOsm} / \mathrm{kg}$. After administration of AVP there was a $74 \%$ increase in urinary osmolality suggestive of central DI. The control did not stabilize his urinary osmolality despite plasma osmolality of $302 \mathrm{mOsm} / \mathrm{kg}$ (Figure 2). All osmolality studies were performed with an osmometer using the freezing point depression method. The patient was put on oral desmopressin $0.1 \mathrm{mg}$ at bed time, following which she had a marked relief in polyuria and is continuing medications to date.

Table 1. Basal thyroid and pituitary hormonal parameters

\begin{tabular}{lccc}
\hline $\begin{array}{l}\text { Hormone } \\
\text { (Plasma) }\end{array}$ & Units & Values & Normal values \\
\hline $\mathrm{T}_{3}$ & $\mu \mathrm{g} / \mathrm{mL}$ & $<0.3$ & $0.7-2.5$ \\
$\mathrm{~T}_{4}$ & $\mu \mathrm{g} / \mathrm{dL}$ & $<1$ & $5.5-13.5$ \\
$\mathrm{TSH}$ & $\mu \mathrm{lU} / \mathrm{mL}$ & 3.31 & $0.5-6.5$ \\
$\mathrm{LH}$ & $\mathrm{IU} / \mathrm{L}$ & 1.18 & $3-12$ \\
$\mathrm{FSH}$ & $\mathrm{IU} / \mathrm{L}$ & 6.53 & $2-6.6$ \\
Prolactin* & $\mu \mathrm{g} / \mathrm{L}$ & 10.47 & $>2$ \\
$\mathrm{GH}^{*}$ & $\mu \mathrm{g} / \mathrm{L}$ & 0.25 & $>3$ \\
Cortisol $^{*}$ & $\mu \mathrm{g} / \mathrm{dL}$ & 8.35 & $>20$ \\
\hline
\end{tabular}

$\mathrm{T}_{3}$ : tri-iodothyronine; $\mathrm{T}_{4}$ : thyroxine; TSH: thyroid stimulating hormone; FSH: follicle stimulating hormone; LH: luteinizing hormone; GH: growth hormone.

* Peak values after insulin tolerance test. Hormone assays performed with specific radioimmunoassay.

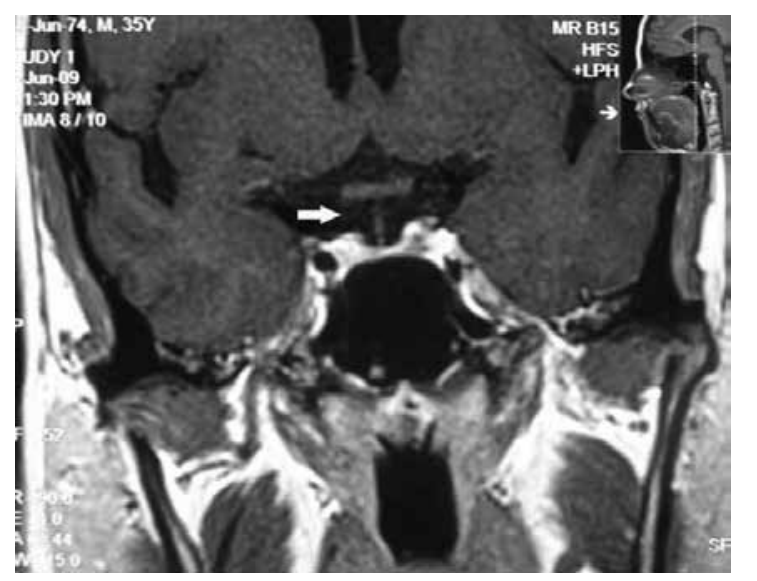

Figure 1. MRI pituitary coronal view showing pituitary fossa filled with cerebrospinal fluid and the stalk touching the atrophic pituitary at the base (arrow) suggestive of complete empty sella. 


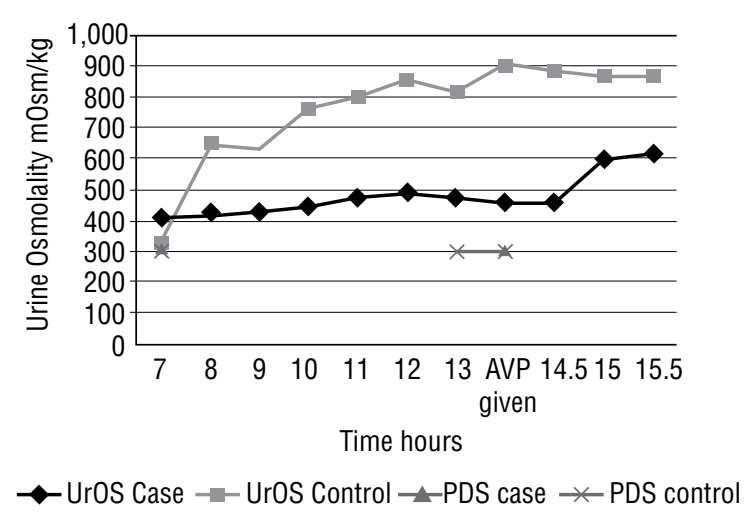

Figure 2. Urine and plasma osmolality and response to AVP in the patient and control during dehydration test. Case: After starting dehydration test at 7 a.m., urine osmolality stabilizes at 1 p.m. when simultaneous plasma osmolality was $300 \mathrm{mOsm} / \mathrm{kg}$. After giving AVP urine osmolality increased to $600 \mathrm{m0sm} / \mathrm{kg}$ in next two hours. Control: in spite of serum osmolality of 300 $\mathrm{m} 0 \mathrm{sm} / \mathrm{kg}$, urine osmolality continued to be of approximately $800 \mathrm{m0sm} / \mathrm{kg}$.

\section{DISCUSSION}

The present patient had classical presentation of Sheehan's syndrome evidenced by history of postpartum hemorrhage followed by lactation failure, amenorrhea, and features of hypothyroidism. Hormonal analysis revealed evidence of panhypopituitarism and MRI revealed features of empty sella. She had a history of polyuria for one year before admission and there was an exacerbation after achieving euthyroid and eucortisolemic states. The water deprivation test documented diabetes insipidus and response to AVP confirmed central diabetes insipidus. Although SS clinically comes to medical attention with features of anterior pituitary hormone deficiency, interest in the posterior pituitary function has been there since the original description of the disease, when Sheehan noticed atrophic changes in the posterior pituitary (11). Posterior pituitary functions have been tested in many series of patients with SS and subtle defects in AVP secretion have been detected (7-10). In one of the recently published series around 29 percent of the patients had partial central diabetes insipidus and the threshold for thirst was increased in all of them (12). Polyuria of the magnitude needing treatment on a permanent basis is rare in patients with SS and data is limited to case reports only. The fact that involvement of the posterior pituitary is less common than that of the anterior pituitary is partly explained by the difference in vascular supply in the two regions. The inferior hypophysial arteries arising from the cavernous portion of the internal carotid artery divide into medial and lateral arteries. These arteries join with those from the opposite side forming an anastomotic ring around the infundibular process of the neurohypophysis and protect it from excessive damage (13).

In one of our large clinical studies previously published; two out of the eighty six patients of SS who had adverse post delivery outcome had Central DI. Both needed nasal desmopressin for control of polyuria and died after six weeks, (5). Tulandi and cols. (14) described the case of a 31-year-old woman who had developed severe bleeding and hypotension after caesarean section. She developed polyuria seven months later and was diagnosed to have diabetes insipidus, imaging of the brain revealed empty sella. Weston and cols. (15) reported a 35-year-old woman with mild preeclampsia and insulin requiring gestational diabetes who presented with postpartum hemorrhage and hypotension requiring subtotal hysterectomy. Postoperatively, she developed excessive thirst, polyuria, severe headaches, and blurry vision. Pituitary function tests revealed central hypothyroidism, hypoprolactinemia, and secondary adrenal failure. Diabetes insipidus was confirmed with electrolyte testing before and after a 10-hour water deprivation test. Imaging showed evidence of ischemic infarction of the pituitary gland. Kan and cols. (9) reported a grand multipara lady who developed severe polyuria after lower segment Cesarean section. She had an estimated blood loss of $500 \mathrm{~mL}$, her hemoglobin dropped from $9.8 \mathrm{~g} / \mathrm{L}$ to $5.7 \mathrm{~g} / \mathrm{L}$ within 24 hours, and she was administered four units of blood. Investigations confirmed central DI and cerebral computed tomography revealed normal pituitary. She required treatment with desmopressin for a few days only. On follow-up she was documented to have panhypopituitarism; was on thyroxine, corticosteroids, and estrogen/progesterone; and diabetes insipidus had resolved. It is possible that the said patient had DI before delivery and was compensating by taking more water and became symptomatic only after water was restricted during the cesarean section or else DI was transient. Recently Kumar and cols. (16) reported a multigravida woman, who developed severe postpartum hemorrhage, disseminated intravascular coagulation followed by Sheehan's syndrome, postoperatively, she developed polyuria, laboratory evidence of diabetes insipidus and her clinical status improved significantly with intranasal Desmopressin supplementation. Patients with SS have elevated AVP levels and increased sensitivity to the hormone before treatment, mainly contributed by a hypocortisol state. If present, $\mathrm{ADH}$ deficiency usually comes to attention after institution of steroid treatment when the subtle 
deficiency becomes symptomatic $(17,18)$. Although the present patient had Polyuria for one year, she became more symptomatic after replacement of prednisolone and thyroxine and required permanent treatment after documentation of central diabetes insipidus.

In summary a young woman developed postpartum hemorrhage, needed blood transfusion after delivery of her $6^{\text {th }}$ child, and subsequently developed Sheehan's syndrome confirmed by hormonal investigation and imaging. She also developed polyuria and was confirmed to have central diabetes insipidus by a water deprivation test. She needed oral desmopressin permanently to be free of polyuria. Permanent central diabetes insipidus in patients with Sheehan's syndrome is rare.

Disclosure: no potential conflict of interest relevant to this article was reported.

\section{REFERENCES}

1. Dejager S, Gerber S, Foubert L, Turpin G. Sheehan's syndrome: differential diagnosis in acute phase. J Intern Med. 1988;244(3):261-6.

2. Goswami R, Kochupillai N, Crock PA, Jaleel A, Gupta N. Pituitary autoimmunity in patients with Sheehan's syndrome. J Clin Endocrinol Metab. 2002;87(9):4137-41.

3. Sheehan $\mathrm{HL}$. The incidence of postpartum hypopituitarism. Am J Obstet Gynecol. 1954;68(1):202-23.

4. Kelestimur F. Sheehan's syndrome. Pituitary. 2003;6(4):181-8.

5. Zargar AH, Masoodi SR, Laway BA, Shah NA, Salahuddin M, Siddiqi $M$, et al. Clinical spectrum of Sheehan's syndrome. Ann Saudi Med. 1996;16(3):338-41.
6. Laway BA, Ganie MA, Wani IR, Butt TP. Multiple spontaneous pregnancies in Sheehan's syndrome with preserved gonadotroph function. Endocrinologist. 2009;19(6):253-4.

7. Bakiri F, Benmiloud M. Antidiuretic function in Sheehan's syndrome. Br Med J. 1984;289(6445):579-80.

8. Jialal I, Desai RK, Rajput MC. An assessment of posterior pituitary function in patients with Sheehan's syndrome. Clin Endocrinol (Oxf). 1987;27(1):91-5.

9. Kan AK, Calligerous D. A case report of Sheehan syndrome presenting with diabetes insipidus. Aust NZ J Obstet Gynaecol. 1998;38(2):224-6.

10. Miller M, Dalakos T, Moses AM, Fellerman H, Streeten DH. Recognition of partial defects in antidiuretic hormone secretion. Ann Intern Med. 1970;73(5):721-9.

11. Sheehan $\mathrm{HL}$, Whitehead R. The neurohypophysis in postpartum hypopituitarism. J Pathol Bacteriol. 1963;85:145-69.

12. Atmaca $\mathrm{H}$, Tanriverdi F, Gokce $\mathrm{C}$, Unluhizarci $\mathrm{K}$, Kelestimur F. Posterior pituitary function in Sheehan's syndrome. Eur J Endocrinol. 2007;156(5):563-7.

13. Jakubowski J. Blood supply, blood flow and auto regulation in the adenohyophysis and altered patterns in oestrogen-induced adenomatous hyperplasia. Br J Neurosurg. 1995;9(3):331-46.

14. Tulandi T, Yusuf N, Posner Bl. Diabetes insipidus: a postpartum complication. Obstet Gynecol. 1987;70(3):492-5.

15. Weston G, Chaves N, Bowditch J. Sheehan's syndrome presenting post-partum with diabetes insipidus. Aust N Z Obstet Gynecol. 2005;45(3):249-50.

16. Kumar S, Burrows D, Dang S, Simmons D. Sheehan's syndrome presenting as central diabetes insipidus: a rare presentation of an uncommon disorder. Endocrine Practice. 2010;1:1-23.

17. Bunch TJ, Dunn WF, Basu A, Gosman RI. Hyponatremia and hypoglycemia in acute Sheehan's syndrome. Gynecol Endocrinol. 2002;16(5):419-23.

18. Diederich S, Franzen NF, Bahr V, Oelkers W. Severe hyponatremia due to hypopituitarism with adrenal insufficiency: report on 28 cases. Eur J Endocrinol. 2003;148(6):609-17. 